\title{
OBSERVATIONS OF THE EFFECT OF ANOXEMIA ON THE HEART
}

\section{Intraventricular Conduction}

By WILLIAM H. RESNIK

(From the Cardiographic Laboratory of the Medical Clinic of The Johns Hopkins Hospital and University)

(Received for publication August 6, 1925)

\section{INTRODUCTION}

In a preceding paper (Resnik, 1925), I have described the changes in auriculo-ventricular conduction which occur as a result of anoxic anoxemia. In this paper, I shall record the effects of anoxemia on intraventricular conduction. It is well known that supraventricular impulses may give rise to aberrant ventricular complexes, that is to say, ventricular complexes which tend to have the form seen in bundle branch block, even when there is no actual anatomical lesion of the branches of the main conduction stem (Lewis, 1920). Robinson (1916) among others, has reported interesting clinical examples of this kind of disturbance of cardiac mechanism; and Lewis (1911-12) has described its appearance in asphyxial experiments. This form of abnormal ventricular complex, when it is not due to gross structural change, is usually seen in patients who exhibit other evidences of functional impairment of the heart, frequently appearing during periods of myocardial failure, and disappearing with improvement of the circulation. Ventricular aberration may also appear when an apparently normal heart is subjected to some unusual strain, such as the unusually rapid rate of beating in paroxysmal tachycardia of auricular origin. The explanation given for the presence of the abnormal form of the ventricular complex under these conditions is that because of failure of complete recovery of one or the other of the bundle branches of the conduction system, the excitation wave travels through the ventricles at unequal rates of speed, the result being that ventricular excitation is set up in an abnormal fashion. 


\section{METHODS}

In an attempt to determine in how far anoxemia may be responsible for changes in conduction through the ventricles, I have measured the QRS intervals in the records taken with lead II in the experiments previously reported (Resnik, 1925). The methods of the experiments have been fully described in the above paper, and it need only be mentioned that the pericardium was unopened in all the present experiments, and that the animals were completely under the influence of atropine. Measurements were made with a Lucus comparator, 11, the average of at least three determinations being taken as the figure for a single record. The same points for measurement were used throughout the different records of a single experiment. These points, chosen for accuracy and convenience of measurement, did not necessarily include the entire QRS interval. The figures for a single record usually fell within 0.002 to 0.003 second. $^{1}$

\section{RESULTS}

The results of four experiments are given in tables 1 to 4 .

In experiments 13 and 19 (tables 1 and 2), there was practically no change in the duration of the QRS interval, such differences as there were falling within the limit of error of measurement. In experiment 17 (table 3) one in which anoxemia was severe but of short duration, and in experiment 15 (table 4) in which a moderate anoxemia was maintained for two and a half hours, the change was still slight, but more definite. In the latter experiment, the figures remained essentially the same, on return to normal oxygen saturation of the blood, as those obtained in the last series during anoxemia, a phenomenon which was frequently observed in studying the effect of anoxemia on auriculoventricular conduction.

Although records were made at higher rates of stimulation, measurements of the QRS interval were not made in these, because the change in the form of the ventricular complexes and the fusion of the auricular and ventricular components of the curves, would have made them inaccurate. At these high rates of stimulation, the $\mathrm{T}$ wave became

1 Throughout the text and in the tables, it will be understood that the arterial blood is meant when reference is made to the oxygen saturation of the blood. 
TABLE 1

Dog 13

\begin{tabular}{|c|c|c|c|c|c|c|c|}
\hline \multicolumn{4}{|c|}{ Oxygen saturation 96 per cent } & \multicolumn{4}{|c|}{$\begin{array}{l}\text { Oxygen saturation } 89 \text { per cent } \\
\text { Started } 12: 46\end{array}$} \\
\hline Time & $\begin{array}{c}\text { Rate of } \\
\text { stimula- } \\
\text { tion }\end{array}$ & $\begin{array}{l}\text { QRS } \\
\text { interval }\end{array}$ & T wave & Time & $\begin{array}{c}\text { Rate of } \\
\text { stimulation }\end{array}$ & $\underset{\text { interval }}{\text { QRS }}$ & $\mathrm{T}$ wave \\
\hline & per minute & second & & & per minute & second & \\
\hline \multirow[t]{4}{*}{$11: 55$} & 212 & 0.043 & Upright & $12: 56$ & 212 & 0.041 & Upright \\
\hline & 243 & 0.043 & Upright & & 243 & 0.042 & Upright \\
\hline & 264 & 0.043 & Upright & & 261 & * & Upright \\
\hline & 285 & 0.042 & Upright & & 277 & 0.039 & Upright \\
\hline $12: 22$ & 323 & 0.041 & Inverted & $1: 00$ & 324 & 0.042 & Inverted \\
\hline
\end{tabular}

* Record not satisfactory for accurate measurement.

TABLE 2

Dog 19

\begin{tabular}{|c|c|c|c|c|c|c|c|}
\hline \multicolumn{4}{|c|}{$\begin{array}{c}\text { Oxygen saturation } 90 \text { per cent } \\
\text { Started 11:40 }\end{array}$} & \multicolumn{4}{|c|}{$\begin{array}{l}\text { Oxygen saturation } 98 \text { per cent } \\
\text { Started } 12: 37\end{array}$} \\
\hline Time & $\begin{array}{l}\text { Rate of } \\
\text { stimula- } \\
\text { tion }\end{array}$ & QRS & $T$ wave & Time & $\begin{array}{c}\text { Rate of } \\
\text { stimulation }\end{array}$ & QRS & $T$ wave \\
\hline & per minute & second & & & per minute & second & \\
\hline \multirow[t]{3}{*}{$12: 19$} & 176 & 0.043 & Upright & $1: 18$ & 148 & 0.043 & Upright \\
\hline & 221 & 0.043 & Upright & & 218 & 0.042 & Upright \\
\hline & 260 & 0.043 & Upright & & 254 & 0.042 & Upright \\
\hline $12: 32$ & 312 & - & Inverted & $1: 26$ & 312 & - & Inverted \\
\hline
\end{tabular}

TABLE 3

\section{Dog 17}

\begin{tabular}{|c|c|c|c|c|c|c|c|}
\hline \multicolumn{4}{|c|}{ Oxygen saturation 86.5 per cent } & \multicolumn{4}{|c|}{$\begin{array}{l}\text { Oxygen saturation } 49 \text { per cent } \\
\text { Started } 11: 57\end{array}$} \\
\hline \multirow[t]{2}{*}{ Time } & $\begin{array}{c}\text { Rate of } \\
\text { stimula- } \\
\text { tion }\end{array}$ & QRS & $\mathrm{T}$ wave & Time & $\begin{array}{c}\text { Rate of } \\
\text { stimulation }\end{array}$ & QRS & $T$ wave \\
\hline & per minute & second & & & per minute & second & \\
\hline \multirow[t]{2}{*}{$11: 30$} & 222 & 0.046 & Upright & $12: 05$ & 226 & 0.042 & Upright \\
\hline & 282 & 0.047 & Upright & & 285 & 0.042 & Upright \\
\hline $11: 38$ & 331 & - & Inverted & $12: 09$ & 330 & - & Inverted \\
\hline
\end{tabular}

negative and the ventricular complex diphasic. It is probable that these ventricular complexes, which may be termed aberrant, represented transitional forms between the normal and those due to well 


\begin{tabular}{|c|c|c|c|c|c|c|c|c|c|c|c|}
\hline \multicolumn{4}{|c|}{ Oxygen saturation 100 per cent } & \multicolumn{4}{|c|}{$\begin{array}{l}\text { Oxygen saturation } 81 \text { per cent } \\
\text { Started } 11: 47\end{array}$} & \multicolumn{4}{|c|}{$\begin{array}{l}\text { Oxygen saturation } 81 \text { per cent } \\
\text { Started 11:47 }\end{array}$} \\
\hline \multirow[t]{2}{*}{ Time } & $\begin{array}{l}\text { Rate of } \\
\text { stimu- } \\
\text { lation }\end{array}$ & QRS & $T$ wave & Time & $\begin{array}{l}\text { Rate of } \\
\text { stimu- } \\
\text { lation }\end{array}$ & QRS & T wave & Time & $\begin{array}{l}\text { Rate of } \\
\text { stimu- } \\
\text { lation }\end{array}$ & QRS & $T$ war \\
\hline & $\begin{array}{c}\text { per } \\
\text { minute }\end{array}$ & second & & & $\begin{array}{c}\text { per } \\
\text { minute }\end{array}$ & second & & & $\begin{array}{c}\text { per } \\
\text { minute }\end{array}$ & second & \\
\hline \multirow[t]{5}{*}{$11: 33$} & 204 & 0.051 & Upright & $11: 57$ & 210 & 0.051 & Upright & $12: 30$ & 201 & 0.049 & Uprigl \\
\hline & 230 & 0.049 & Upright & & 234 & 0.053 & Upright & & 226 & 0.049 & Uprigl \\
\hline & 257 & 0.053 & Upright & & 266 & 0.052 & Upright & & 256 & 0.051 & Uprigl \\
\hline & & & & & 286 & 0.049 & Upright & & 280 & 0.050 & Uprigl \\
\hline & 301 & 0.056 & Upright & & 306 & 0.051 & Upright & & 307 & 0.051 & Uprigl \\
\hline $11: 40$ & 335 & * & Inverted & $12: 03$ & 342 & 0.053 & Inverted & $12: 36$ & 344 & $*$ & Invert \\
\hline
\end{tabular}

* Record not satisfactory for accurate measurement.

developed bundle branch block, in spite of the fact that there was no conspicuous widening of the QRS interval. Wilson (1915) found that the most constant feature of transitional complexes was their diphasic character. I have therefore noted in the tables given above the direction of the $T$ wave. Using this as a criterion, it is again apparent that anoxemia produced no striking changes in intraventricular conduction.

In one experiment, no. 19 (table 5), a severe degree of anoxemia was instituted and maintained until the animal died, the rate of stimulation being approximately 220 per minute for each record.

In this experiment there was a gradual increase in the QRS interval, slight, however, until just before the animal died.

At rapid rates of stimulation there was occasionally observed alternation in the height of the ventricular complexes and in the width of the QRS interval. Thus, in experiment 13, the following figures for successive ventricular cycles were obtained at the rate of 323 per minute: $0.0407,0.0392,0.0427,0.0405,0.0427,0.0398,0.0426$, $0.0403,0.0417,0.0432,0.0418$. There was no greater tendency for these phenomena to occur in either the periods of low or normal oxygen saturation of the arterial blood.

It may be mentioned that there was a very definite tendency for ventricular fibrillation to develop during anoxemia, particularly when the anoxemia was severe and prolonged. This arrhythmia 


\begin{tabular}{|c|c|c|c|c|c|c|c|c|c|c|c|}
\hline \multicolumn{4}{|c|}{$\begin{array}{l}\text { Oxygen saturation } 81 \text { per cent } \\
\text { Started 11:47 }\end{array}$} & \multicolumn{4}{|c|}{$\begin{array}{l}\text { Oxygen saturation } 81 \text { per cent } \\
\text { Started 11:57 }\end{array}$} & \multicolumn{4}{|c|}{$\begin{array}{l}\text { Oxygen saturation } 97 \text { per cent } \\
\text { Started 2:16 }\end{array}$} \\
\hline ne & $\begin{array}{c}\text { Rate of } \\
\text { stimu- } \\
\text { lation }\end{array}$ & QRS & $\mathbf{T}$ wave & Time & $\begin{array}{l}\text { Rate of } \\
\text { stimu- } \\
\text { lation }\end{array}$ & QRS & $T$ wave & Time & $\begin{array}{l}\text { Rate of } \\
\text { stimu- } \\
\text { lation }\end{array}$ & QRS & $T$ wave \\
\hline & $\underset{\text { minute }}{\text { per }}$ & second & & & $\begin{array}{c}\text { per } \\
\text { minute }\end{array}$ & second & & & $\begin{array}{c}\text { per } \\
\text { minute }\end{array}$ & second & \\
\hline \multirow[t]{5}{*}{15} & 205 & 0.050 & Upright & & & & & $3: 01$ & 207 & 0.046 & Upright \\
\hline & 220 . & 0.048 & Upright & $2: 01$ & 229 & 0.047 & Upright & & 222 & 0.046 & Upright \\
\hline & 254 & 0.048 & Upright & & 260 & 0.048 & Upright & & 257 & 0.047 & Upright \\
\hline & 279 & 0.048 & Upright & & 282 & 0.049 & Upright & & 282 & 0.048 & Upright \\
\hline & 301 & 0.049 & Upright & & 304 & 0.051 & Upright & & 303 & 0.048 & Upright \\
\hline 21 & 337 & 0.050 & Inverted & $2: 10$ & 341 & $*$ & Inverted & $3: 10$ & 330 & 0.050 & Inverted \\
\hline
\end{tabular}

TABLE 5

Dog 19. Normal QRS interval at rate of 218 is 0.042 second. (Oxygen saturation 98 per cent)

\begin{tabular}{|c|c|c|c|}
\hline \multirow{2}{*}{ Time } & \multicolumn{3}{|c|}{$\begin{array}{l}\text { Oxygen saturation } 41 \text { per cent } \\
\text { Started } 1.28\end{array}$} \\
\hline & Rate of stimulation & QRS & $T$ wave \\
\hline & per minute & second & \\
\hline $1: 30$ & 218 & 0.041 & Upright \\
\hline $1: 30.30$ & 222 & 0.041 & Upright \\
\hline $1: 38$ & 220 & 0.041 & Upright \\
\hline $1: 41$ & 224 & 0.042 & Slightly inverted \\
\hline $1: 45$ & 226 & 0.042 & Slightly inverted \\
\hline $1: 50$ & 224 & 0.045 & Slightly inverted \\
\hline $1: 55$ & 220 & 0.044 & Slightly inverted \\
\hline $2: 00$ & 224 & 0.045 & Slightly inverted \\
\hline $2: 06$ & 220 & 0.047 & Slightly inverted \\
\hline $2: 10$ & 219 & $0.063^{*}$ & Diphasic \\
\hline $2: 14$ & 220 & $\begin{array}{l}\text { Ventricular fibril- } \\
\text { lation }\end{array}$ & \\
\hline
\end{tabular}

* $\mathbf{R}$ notched; low voltage.

occasionally appeared spontaneously; more often it occurred on the lightest handling of the ventricles.

\section{DISCUSSION}

These experiments are few in number, but they give a fairly clear idea of the effect of anoxemia on the QRS interval. No definite altera- 
tions took place except when the anoxemia was of long duration or of marked severity. These results are similar to those of Lewis (1911-12) who found that, whereas asphyxia produced uniformly profound disturbances in auriculo-ventricular conduction, only occasionally were aberrant ventricular complexes present in the same experiments. Moreover, in his experiments the abnormal ventricular complexes were not typical examples of complete bundle branch block, and occurred, apparently, only in the late stages of asphyxiation.

While the changes are slight, showing that the tissues which transmit the wave of excitation through the ventricles are relatively resistant to anoxemia, they are similar in character to those which occurred in auriculo-ventricular conduction, for shortening of the QRS interval appeared first, but was followed by lengthening later. The alterations in intraventricular conduction seen in these experiments were not nearly so conspicuous as many of the clinical examples which have been reported. Yet, it must be emphasized again, that these observations were made almost always in patients who showed other evidence of myocardial disease. The inference that may be drawn, then, is that when ventricular aberration, independent of organic lesions of the bundles of the main conduction stem, is not due to an unusually rapid heart rate (when it may appear in the normal heart with the arterial blood normally saturated with oxygen) it is an indication of a more or less severe functional impairment of the myocardium. This view is based on the assumption that incomplete recovery of the bundle branches, to which aberration of the ventricular complexes is attributed, is due fundamentally to a defective oxygen supply to the myocardium. The anoxemia of myocardial failure, for example, possibly insufficient in itself to bring about intraventricular conduction defects, makes its effects evident when it becomes engrafted on a latent functional impairment of the Purkinje tissue.

SUMMARY AND CONCLUSIONS

1. In the normal heart, anoxemia produces comparatively slight changes in intraventricular conduction.

2. These changes are similar in character, though much less 
marked than those which occur in auriculo-ventricular conduction: at first the QRS interval shortens, later it lengthens.

3. It is probable that ventricular aberration in clinical cases is an indication of more or less serious disturbance of the function of the Purkinje tissues.

4. Ventricular fibrillation is prone to develop during anoxemia.

\section{BIBLIOGRAPHY}

Lewis, T.: Heart, 1911-12, iii, 161. Observations upon Disorders of the Heart's Action.

Lewis, T.: London, 1920. The Mechanism and Graphic Representation of the Heart Beat.

Robinson, G. C.: Arch. Int. Med., 1916, xviii, 830. The Relation of Changes in the Form of the Ventricular Complex of the Electrocardiogram to Functional Changes in the Heart.

Resnik, W. H.: Jour. Clin. Invest., 1925, ii, 93. Observations on the Effect of Anoxemia on the Heart. I. Auriculo-ventricular Conduction.

Wilson, F. N.: Arch. Int. Med., 1915, xvi, 108. A Case in which the Vagus Influenced the Form of the Ventricular Complex of the Electrocardiogram. 